\title{
Effect of Balloon-Blowing on Dyspnea and Oxygenation in Noncritical Adult Covid19 Patients: A Pilot Study
}

This study was registered at the Iranian Registry of Clinical Trial. (IRCT registration number: IRCT20201012049010N1)

\section{Authors' Affiliations and Names:}

1. * Mohammad Bargahi, Qazvin University of Medical Sciences, Qazvin, Iran.

(*Corresponding Author) e-mail: mmd.bargahi@gmail.com

2. Soheil Soltani, Qazvin University of Medical Sciences, Qazvin, Iran.

3. Nafiseh Rastgoo, Metabolic Diseases Research Center, Research Institute for Prevention of Non-Communicable Diseases, Qazvin University of Medical Sciences, Qazvin, Iran.

4. Farzane Aryanejad, Qazvin University of Medical Sciences, Qazvin, Iran.

5. Roomina Nemati, University Of Texas at Arlington, Arlington, Texas, USA .

6. Mehdi Ghaebi, Qazvin University of Medical Sciences, Qazvin, Iran.

7. Arezoo Bajelan, Qazvin University of Medical Sciences, Qazvin, Iran.

8. Sohrab Esmaielzade, Qazvin University of Medical Sciences, Qazvin, Iran. 
medRxiv preprint doi: https://doi.org/10.1101/2021.07.27.21260398; this version posted July 27, 2021. The copyright holder for this preprint

\section{Abstract}

\section{Effect of Balloon-Blowing on Dyspnea and Oxygenation in Noncritical Adult Covid-19 Patients: A Pilot Study}

Mohammad Bargahi, Soheil Soltani, Nafiseh Rastgoo, Farzane Aryanejad, Sohrab Esmaielzade, Roomina Nemati, Mehdi Ghaebi, Arezoo Bajelan

Dyspnea and decreased $\mathrm{O} 2$ saturation are the most common causes of hospitalization in noncritical covid-19 patients. Breathing exercises and chest physiotherapy are used for managing the patients. These treatments are however not well supported by scientific evidence. In a randomized controlled trial, 80 patients were randomly assigned to planned breathing-exercise $(n=40)$ and control groups $(n=40)$. The participants in the intervention group were instructed to blow into a balloon five times a day while lying down. Other therapies were similar in both groups. The severity of dyspnea at rest/after activity and peripheral oxygen saturation $(\mathrm{SpO} 2)$ with/without $\mathrm{O} 2$ therapy were compared between the two groups on the first, second, and third days. The study findings showed no statistically significant difference in $\mathrm{SpO} 2$ with/without O2 therapy on the first, second, and third days between the two groups. Although the severity of dyspnea showed no significant difference between the two groups, the mean score of dyspnea at rest $(2.72 \pm 2.25$ vs. $1.6 \pm 1.21, \mathrm{p}=0.007)$ and after activity $(4.53 \pm 2.04$ vs. $3.52 \pm 1.66, \mathrm{P}=0.017)$ improved in the intervention group on the third day. Balloon-blowing exercise improves dyspnea in noncritical Covid-19 patients, but it does not significantly improve oxygenation.

Keywords: breathing exercises, balloon-blowing, BBE, chest physiotherapy, covid-19, dyspnea, oxygenation, pulmonary rehabilitation. 
medRxiv preprint doi: https://doi.org/10.1101/2021.07.27.21260398; this version posted July 27, 2021. The copyright holder for this preprint

\section{Introduction}

Severe Acute Respiratory Syndrome Coronavirus-2 (SARS-CoV-2) has been designated as the cause of a highly infectious pandemic called Coronavirus Disease 2019 (COVID-19), which is spread mainly through respiratory droplets and close contact. (1) The presentations of COVID-19 are highly variable, with most of the patients $(80 \%)$ experiencing mild/no symptoms and a minority suffering from pneumonia, severe respiratory failure, acute respiratory distress syndrome (ARDS), or even death (3-5\%).

SARS-CoV-2 attacks the respiratory epithelial cells, causing cough, dyspnea, and fever. It induces exudates of serous fluid, fibrin, and hyaline membrane formation within the alveoli. (4) A chest CT-scan may show varying patterns of lung involvement including bilateral, multilobar ground glass opacification (GGO) with a peripheral/posterior distribution mainly in the lower lobes. (5) Parenchymal pathological alterations in the form of exudative diffuse alveolar damage are also seen with different degrees of extension. (6) These pathologies can cause profound hypoxemia with near normal arterial carbon dioxide levels due to ventilation/perfusion $(V / Q)$ mismatch and unventilated lung units. The inability to gas exchange often resembles typical ARDS as the disease progresses.(2) Additionally, acute lung injury elicits systemic inflammation and increases pro-inflammatory cytokine expression. (2)(7)

About $20 \%$ of COVID-19 patients need hospitalization. One third $(32.8 \%)$ of the patients experience ARDS during their hospital stay. ${ }_{(8)}$ Studies have shown that early pulmonary rehabilitation (PR) interventions within two days of admission can reduce mortality in patients with community-acquired pneumonia and interstitial pneumonia. (9) The primary objectives of PR in this stage are to promote airway clearance and prevent complications of acute illness-related immobilization. Proper incorporation of PR into medical treatment could promote effective expectoration, facilitate mucus clearance, and mobilize secretions to the upper airways thereby improving lung volumes, perfusion, and oxygenation. (9) (10) (11) In addition, PR may help to prevent or mitigate sequelae related to bed rest, thus improving physical function and outcomes and reducing the length of hospital stay by increasing ventilator free days. (9) (4)

Although there is still no evidence about the efficacy of PR in the specific setting of COVID-19, several established physiotherapy techniques are safely recommended to improve outcomes. (9)(10) PR has different techniques including breathing exercises (BE) and chest physiotherapy. Balloon-Blowing Exercise $(\mathrm{BBE})$ is a simple, cost-effective, non-personnel dependent BE that can improve 
medRxiv preprint doi: https://doi.org/10.1101/2021.07.27.21260398; this version posted July 27, 2021. The copyright holder for this preprint

lung capacities and respiratory function (12) in people with chronic obstructive pulmonary disease and lower respiratory tract disorders and elderly smokers.

$(13)(14)(15)$

To the best of our knowledge, this is the first trial of the use of a specific BE in covid-19 patients in the acute setting. This study was conducted to evaluate the effects of BBE on dyspnea and oxygenation in covid-19 patients in the acute phase.

\section{Method}

The Participants in this study were selected from patients admitted to the nonintensive care unit (ICU) of Booali-Sina Educational and Medical Hospital, Qazvin, Iran, which was designated for covid-19 patients by the relevant governmental committee, from August 15, 2020 to October 31, 2020.

Inclusion criteria: 1 ) age $\geq 18$ year, 2) definitive covid-19 diagnosis (RT$\mathrm{PCR}+$ / chest $\mathrm{CT}+$ ), 3) first day of admission in the ward, 4) presence of dyspnea according to the patient's statement, 5) peripheral oxygen saturation $(\mathrm{SpO} 2)<94 \%$.

Exclusion criteria: 1) pregnancy, 2) history of lung disease (under treatment), kidney disease (under treatment), heart disease, or neurological disease, 3) allergy to latex or balloon material, 4) contraindication to intense aerobic activity by a physician, and 5) need for hospitalization in the ICU/CCU based on the diagnostic and treatment flowchart of the Ministry of Health, $7^{\text {th }}$ edition (16).

This study had a randomized controlled design. The patients who met the inclusion criteria were selected and divided into two groups included intervention and control groups based on random number blocks designed by Excel software. Both groups received the same treatments and oxygen therapy according to the flowchart ${ }^{(16)}$.

The intervention group was instructed to blow into a balloon at least five sets a day each consisting of five repetitions of BBE in the supine position. They were instructed to inflate the balloon, rest as long as they required, and then blow it again for each set. For BBE, the patients were asked to take a deep breath for 25 seconds, hold it in for two seconds, and then inflate the balloon as many times as they could. As a substitute for the balloon when the patient was unable to inflate it, a latex glove size six was used. The balloons and latex gloves were replaced every day. Eleven-inch oval rubber balloons were used. 
medRxiv preprint doi: https://doi.org/10.1101/2021.07.27.21260398; this version posted July 27, 2021. The copyright holder for this preprint

(which was not certified by peer review) is the author/funder, who has granted medRxiv a license to display the preprint in perpetuity.

It is made available under a CC-BY-NC-ND 4.0 International license.

Assessment: The patients were assessed on days 1 (before the intervention), 2 and 3. The following data were collected:

1) The participants were evaluated for dyspnea severity using The Modified 0-10 Borg Dyspnea Scale (MBS) every day. All patients received this scale in textual and visual forms. After sitting for five minutes (resting) and walking 50 meters while wearing a finger pulse oximeter (activity), the patients were asked to rate the severity of their dyspnea on a scale of 0 to 10. Santamedical Generation 2 Fingertip Oximeter (Gurin Products) was used.

2) $\mathrm{SpO} 2$ was measured during oxygen therapy and after five minutes without oxygen therapy using the above pulse oximeter. In both conditions, the pulse oximeter was worn on the finger and the $\mathrm{SpO} 2$ value was recorded after two minutes.

Study termination: The criteria for study termination were a $\mathrm{SpO} 2$ drop of more than $15 \%$, a deterioration of more than $20 \%$ in the severity of dyspnea, and need for treatment regimen change according to the medical team.

Statistical analysis: The collected data were analyzed using the IBM SPSS software version 26 in two unlabeled groups. This pilot study was conducted to estimate the sample size needed for future studies due to lack of data and the innovation of the method used. Unpaired t-test was used to analyze all variables between the two groups. One-way ANOVA test was applied to analyze the variables of each group between various days. Statistical significance was set at $\leq 0.05$.

Ethical considerations The Ethics and Research Committee of Qazvin University of Medical Sciences approved this study (IR.QUMS.REC.1399.043). Informed written consent was obtained from all participants following a detailed explanation of the examination and study procedures.

\section{RESULTS}

Eighty-six patients were selected of whom three patients refused to participate in the study. Two patients were excluded from the intervention group due to their reluctance to continue the evaluations. One patient was also excluded from the control group after the second day as a result of a change in his treatment regimen. Finally, 80 patients, including 49 men and 31 women, completed the study. (Fig.1)

The patients were randomly assigned to control and intervention groups. Both groups received the same drug treatment regimen determined by the relevant 
medRxiv preprint doi: https://doi.org/10.1101/2021.07.27.21260398; this version posted July 27, 2021. The copyright holder for this preprint (which was not certified by peer review) is the author/funder, who has granted medRxiv a license to display the preprint in perpetuity. It is made available under a CC-BY-NC-ND 4.0 International license .

medical team. There was no statistically significant difference in gender, age, body mass index (BMI), and extent of pulmonary involvement on CT scan between the groups. (Table.1)

$\mathrm{SpO} 2$ values were compared between the two groups. Twelve participants (15\%) showed no increase in the $\mathrm{SpO} 2$ value without $\mathrm{O} 2$ therapy after three days, of whom four (5\%) were in the intervention group and eight (10\%) in the control group. However, both groups showed relative improvement on days two and three. Nevertheless, there was no statistically significant difference between the two groups on the first to third day $(\mathrm{p}>0.05)$. The SpO2 levels with/without $\mathrm{O} 2$ therapy after three days were better in the intervention group compared to the control group (2.8 \pm 4.8 vs. $2.8 \pm 2.7$, and $4.8 \pm 4.3$ vs. $3.2 \pm 2.7)$, but the differences were not statistically significant ( $p>0.05)$. (Table.2, Fig.2)

There was no significant difference in dyspnea at rest or after activity between the two groups based on MBS on the first day. Breathing improved in both groups on the second and third day; there was no significant difference on the second day ( $p>0.05)$ while a significant difference was found between the BBE and the control group (at rest and after activity) on the third day of the trial $(\mathrm{p} \leq 0.05)$. (Table.2, Fig.3)

Additionally, the participants in case and control groups were divided into four subgroups based on their $\mathrm{SpO} 2$ value without $\mathrm{O} 2$ therapy on the first day for a more accurate assessment, including SG1 (SpO2<80\%), SG2 $(80 \% \leq \mathrm{SpO} 2<85 \%), \mathrm{SG} 3(85 \% \leq \mathrm{SpO} 2<90 \%)$, and $\mathrm{SG} 4(\mathrm{SpO} 2 \leq 90 \%)$. (Table.3) All intervention subgroups experienced an increase in $\mathrm{SpO} 2$ levels on the second and third days except for SG4 that had a decrease on the third day compared to the second day. The changes in $\mathrm{SpO} 2$ levels in the intervention subgroups SG1 to SG4 were 4.2, 2.3, 2.6 and 1.6 with $\mathrm{O} 2$ therapy and 8.8, 4.2, 2.6 and 3 without $\mathrm{O} 2$ therapy. (Fig.4) After three days of BBE, there was no statistically significant difference in the $\mathrm{SpO} 2$ level change with/without $\mathrm{O} 2$ therapy between the same subgroups in the control and intervention groups $(p>0.05)$.

(Table.3, Fig.4)

\section{Discussion}

Dyspnea and decreased $\mathrm{SpO} 2$ are the most common causes of hospitalization in covid-19 patients. As mentioned earlier, 20\% of covid-19 patients need to be hospitalized due to oxygen-equiring lung infection and one third develop a severe form of the disease. (3)(8) The most important causes of disease progression may be long-term $\mathrm{O} 2$ therapy injuries as well as $\mathrm{V} / \mathrm{Q}$ mismatch. (2)(6) Studies have shown that early PR can reduce mortality by clearing the airways as well as improving lung capacity and thus improving gas exchange in 
medRxiv preprint doi: https://doi.org/10.1101/2021.07.27.21260398; this version posted July 27, 2021. The copyright holder for this preprint

patients with interstitial pneumonia. (9)(10)(11) In a study by Smita Manjusha Das (2018) et al., children aged 3 to 12 years were randomized to receive either balloon or bubble therapy for six days. Among 60 participants, 29 had pneumonia, 17 had bronchitis, and 14 had bronchiolitis. The study reported a significant improvement in $\mathrm{SpO} 2$ after regular balloon/bubble inflation. (17) This finding is in contrast to our study where the BBE group did not show a significant improvement in $\mathrm{SpO} 2$ level with/without $\mathrm{O} 2$ therapy after three days of $\mathrm{BBE}$ compared to the control group. A possible explanation is the difference in BBE days.

In the present study, the severity of dyspnea at rest/after activity reduced significantly after three days of BBE in the intervention group compared to the control group. These findings were consistent with the results of a study conducted by Renuka K (2015) et al. on the respiratory status of patients with lower respiratory tract disorders. In that study, 20 patients received balloon therapy for about 14 consecutive days. The dyspnea scale was measured as a pre/post-test. The study reported a significant reduction in dyspnea after regular balloon inflation. (18) Combined with our data, it is suggested that the use of BBE is useful in reducing the dyspnea severity in the early days of diagnosis.

There is still controversy about PR strategies in the acute phase of the covid-19. Since BE increases the work of breathing muscles and blood oxygenation alteration leads to a rapid and shallow respiratory pattern, Marta Lazzeri (2020) et al. recommended avoiding such a procedure in the acute setting. (19) None of our BBE participants met the termination criteria. In the present study, most of the patients in the $\mathrm{BBE}$ group reported mild dizziness and difficulty inflating the balloon on the second day. Almost all the patients reported an improvement in their ability to breathe and felt stronger in their chest on the third day. The balloons were not replaced with latex gloves in any of the patients. According to the results, BBE can be done safely in patients with covid-19 in the acute phase. Furthermore, it is highly recommended that patients undergo regular monitoring during $\mathrm{BBE}$.

This study had several limitations. Because of the nature of rehabilitation and assessment, neither the executors nor the participants could be blinded.

Therefore, it is not possible to rule out the placebo effect, observer bias or experimenter bias in the current study. In addition, the subjects were limited to patients aged 18 years and above, the duration of the intervention was only three days, and the number of participants was insufficient in each group. Eventually, we did not measure other variables such as the respiratory rate, pulse rate, lung capacities, and anxiety score. Therefore, future studies should address these limitations. 
medRxiv preprint doi: https://doi.org/10.1101/2021.07.27.21260398; this version posted July 27, 2021. The copyright holder for this preprint (which was not certified by peer review) is the author/funder, who has granted medRxiv a license to display the preprint in perpetuity.

\section{Conclusions}

According to the present study, BBE is a safe medical intervention in noncritical covid-19 patients. It did not significantly improve oxygenation in noncritical covid-19 patients after three days, but it reduced the severity of dyspnea.

\section{Contributors}

M. B. conceived, designed, and wrote the manuscript. M. B., N. R., F. A., S. E., and A. B. BBE guidance, data collection, and follow-up of patients. M. B., N. R., and M.G. entered and analyzed data. S. S., M. B, and R. N. edited and reviewed the manuscript. S. S., and M. B. directed and managed the planning and execution of the project. All authors reviewed and approved the final version of the manuscript.

\section{Funding}

This study was mainly supported by Qazvin University of Medical Science.

\section{Conflicts of interest}

All authors report no potential conflicts.

\section{References}

1. Y.C. Wu, C. C. (2020). The outbreak of COVID-19: an overview. J. Chin. Med. Assoc., 83, $217-$ 220. doi:https://doi.org/10.1097/JCMA.0000000000000270

2. Simonson, T. S., Baker, T. L., Banzett, R. B., Bishop, T., Dempsey, J. A., Feldman, J. L., \& et al. (2020). Silent hypoxaemia in COVID-19 patients. J Physiol, 1057-65. doi:10.1113/JP280769

3. Wu, Z., \& McGoogan, J. M. (2020). Characteristics of and Important Lessons From the Coronavirus Disease 2019 (COVID-19) Outbreak in China: Summary of a Report of 72314 Cases From the Chinese Center for Disease Control and Prevention. JAMA, 323(13), 1239-1242. doi:10.1001/jama.2020.2648

4. Liu, K., Zhang, W., Yang, Y., Zhang, J., Li, Y., \& Chen, Y. (2020). Respiratory rehabilitation in elderly patients with COVID-19: A randomized controlled. Complementary Therapies in Clinical Practice. doi:https://doi.org/10.1016/j.ctcp.2020.101166

5. Salehi, S., Abedi, A., Balakrishnan, S., \& Gholamrezanezhad, A. (2020). Coronavirus Disease 2019 (COVID-19): A Systematic Review of Imaging Findings in 919 Patients. AJR, 87-93.

doi:doi.org/10.2214/AJR.20.23034 
medRxiv preprint doi: https://doi.org/10.1101/2021.07.27.21260398; this version posted July 27,2021 . The copyright holder for this preprint (which was not certified by peer review) is the author/funder, who has granted medRxiv a license to display the preprint in perpetuity.

It is made available under a CC-BY-NC-ND 4.0 International license .

6. Mauad, T. D.-N. (2021). Tracking the time course of pathological patterns of lung injury in severe COVID-19. Respir Res. doi:https://doi.org/10.1186/s12931-021-01628-9

7. Serebrovska, Z. O., Chong, E. Y., Serebrovska, T. V., Tumanovska, L. V., \& Xi, L. (2020). Hypoxia, HIF-1 $\alpha$, and COVID-19: from pathogenic factors to potential therapeutic targets. Acta Pharmacologica Sinica, 1-8. doi:https://doi.org/10.1038/s41401-020-00554-8

8. Johnson, K. D., Harris, C., Cain, J. K., Hummer, C., Goyal, H., \& Perisetti, A. (2020). Pulmonary and Extra-Pulmonary Clinical Manifestations of COVID-19. Front. Med. J., 526. doi:10.3389/fmed.2020.00526

9. Battaglini, D., Robba, C., Caiffa, S., Ball, L., Brunetti, I., Loconte, M., \& et al. (2020). Chest physiotherapy: An important adjuvant in critically ill mechanically ventilated patients with COVID19. Respiratory Physiology \& Neurobiology. doi:https://doi.org/10.1016/j.resp.2020.103529

10. Cheng, Y. Y., Chen, C. M., Huang, W. C., Chiang, S. L., Hsieh, P. C., Lin, K. L., \& et al. (2020). Rehabilitation programs for patients with COronaVIrus Disease 2019: consensus statements of Taiwan Academy of Cardiovascular and Pulmonary Rehabilitation. Journal of the Formosan Medical Association. doi:https://doi.org/10.1016/j.jfma.2020.08.015

11. Strickland SL, R. B. (2013). AARC clinical practice guideline: effectiveness of nonpharmacologic airway clearance therapies in hospitalized patients. 2013;58:2187e93. Respir Care, 2187-93.

12. Seo, K., \& Cho, M. (2018). The effects of a balloon-blowing exercise in a 90/90 bridge position using a ball on the pulmonary function of females in their twenties. Journal of physical therapy science, 30(10), 1267-1270. doi:10.1589/jpts.30.1267

13.Karipa, A. (2017). Effectiveness of balloon exercise on level of dyspnoea among patients with lower respiratory tract disorder. J Lung Pulm Respir Res, 44-49. doi:10.15406/jlprr.2017.04.00119

14. Tunik , T., Rosa, E. M., \& Khoiriyati, A. (2017). The Effectiveness of Breathing Relaxation with Ballon Blowing Technique toward Physiological Changes of COPD Patients. The 5th AASIC (pp. 7276). Thailand: Indonesian Student Association in Thailand (PERMITHA). Retrieved from www.aasic.org: http://aasic.org/proc/aasic/article/view/273

15. Jun, H. J., Kim, K. J., Nam, K. W., \& Kim, C. H. (2016). Effects of breathing exercises on lung capacity and muscle activities of elderly smokers. J Phys Ther Sci, 1681-5. doi:10.1589/jpts.28.1681

16. Ministry of Health, T. a. (2020). Flowchart Diagnosis and Treatment of Covid 19 Disease in Outpatient and Inpatient Service Provisions: Seventh Edition. Ministry of Health, Treatment and Medical Education of Iran. Retrieved from www.irimc.org:

https://learn.irimc.org/media/upload/1399/04/7_dastoor_flochart_treatment_covid_19-

5f0d57f48b6b5.pdf

17. Das, S. M., Nayak, G. R., \& Pradhan, R. (2018, January). Effect of Balloon Therapy vs. Bubble Therapy on LRTI among 3-12 Years Children. International Journal of Health Sciences and Research, 144-147. Retrieved from www.ijhsr.org: https://www.ijhsr.org/IJHSR_Vol.8_Issue.1_Jan2018/IJHSR_Abstract.022.html

18. Renuka, K., Helen , J. S., \& Kripa , A. A. (2015). Effectiveness of Balloon Therapy on Respiratory Status of Patients with Lower Respiratory Tract Disorders. International Journal of Science and Research (IJSR), 496 - 500. Retrieved from www.ijsr.net:

https://www.ijsr.net/search_index_results_paperid.php?id=SUB151952 
medRxiv preprint doi: https://doi.org/10.1101/2021.07.27.21260398; this version posted July 27,2021 . The copyright holder for this preprint (which was not certified by peer review) is the author/funder, who has granted medRxiv a license to display the preprint in perpetuity.

It is made available under a CC-BY-NC-ND 4.0 International license .

19. Lazzeri , M., Lanza, A., Bellini, R., Bellofiore, A., Cecchetto, S., Colombo, A., Frigerio, P., \& et al. (2020). Respiratory physiotherapy in patients with COVID-19 infection in acute setting: a Position Paper of the Italian Association of Respiratory Physiotherapists (ARIR). J Phys Ther Sci, 545-549. doi:10.4081/monaldi.2020.1285

20. CONSORT GROUP. (2010). www.consort-statement.org. Retrieved from http://www.consortstatement.org: http://www.consort-

statement.org/download/Media/Default/Downloads/CONSORT\%202010\%20Flow\%20Diagram.doc 
medRxiv preprint doi: https://doi.org/10.1101/2021.07.27.21260398; this version posted July 27,2021 . The copyright holder for this preprint (which was not certified by peer review) is the author/funder, who has granted medRxiv a license to display the preprint in perpetuity.

It is made available under a CC-BY-NC-ND 4.0 International license.

Fig.1. Flow diagram of study (20)

\section{Enrollment}

Assessed for eligibility $(n=86)$

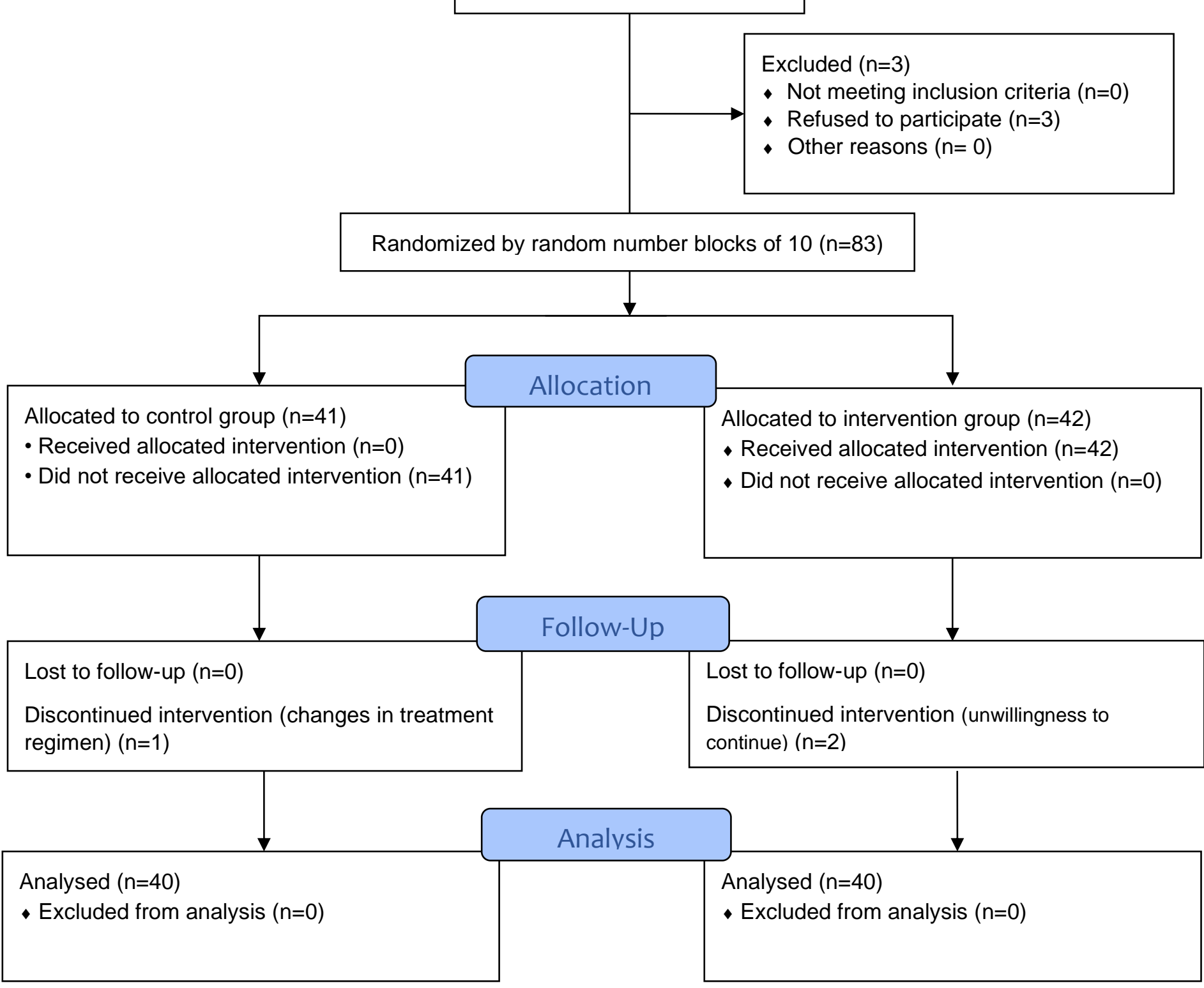


medRxiv preprint doi: https://doi.org/10.1101/2021.07.27.21260398; this version posted July 27,2021 . The copyright holder for this preprint (which was not certified by peer review) is the author/funder, who has granted medRxiv a license to display the preprint in perpetuity.

It is made available under a CC-BY-NC-ND 4.0 International license .

Fig.2. Changes in $\mathrm{O} 2$-sat level with and without $\mathrm{O} 2$ therapy during the study

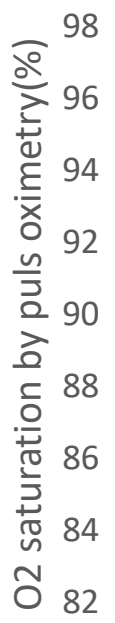

Changes in $\mathrm{O} 2$ sat with/without $\mathrm{O} 2$ therapy

Day 1

Day 2

Day 3

O2sat with $\mathrm{O} 2$ therapy-intervention $\leftrightarrow$ O2sat without 02 therapy-intervention
- O2sat with 02 therapy-control $\cdots 02$ 02sat without $\mathrm{O} 2$ therapy-control 
medRxiv preprint doi: https://doi.org/10.1101/2021.07.27.21260398; this version posted July 27,2021 . The copyright holder for this preprint (which was not certified by peer review) is the author/funder, who has granted medRxiv a license to display the preprint in perpetuity.

It is made available under a CC-BY-NC-ND 4.0 International license .

Fig.3. Changes in Modified 0-10 Borg Scale at rest and after activity during the study

Changes in Modified Borg Scale -at rest/after activity

8

6

4

2

0

Day 1

Day 2

Day 3

-Modified Borg Scale at rest-intervention

..*.. Modified Borg Scale at rest-control

$\longrightarrow$ Modified Borg Scale after activity-intervention

$-\bullet$ Modified Borg Scale after activity-control 
medRxiv preprint doi: https://doi.org/10.1101/2021.07.27.21260398; this version posted July 27,2021 . The copyright holder for this preprint (which was not certified by peer review) is the author/funder, who has granted medRxiv a license to display the preprint in perpetuity.

It is made available under a CC-BY-NC-ND 4.0 International license .

Fig.4. Changes in $\mathrm{O} 2$-sat level with and without $\mathrm{O} 2$ therapy among intervention subgroups during the study

\section{Changes in $\mathrm{O} 2$ sat with/without $\mathrm{O} 2$ therapy}

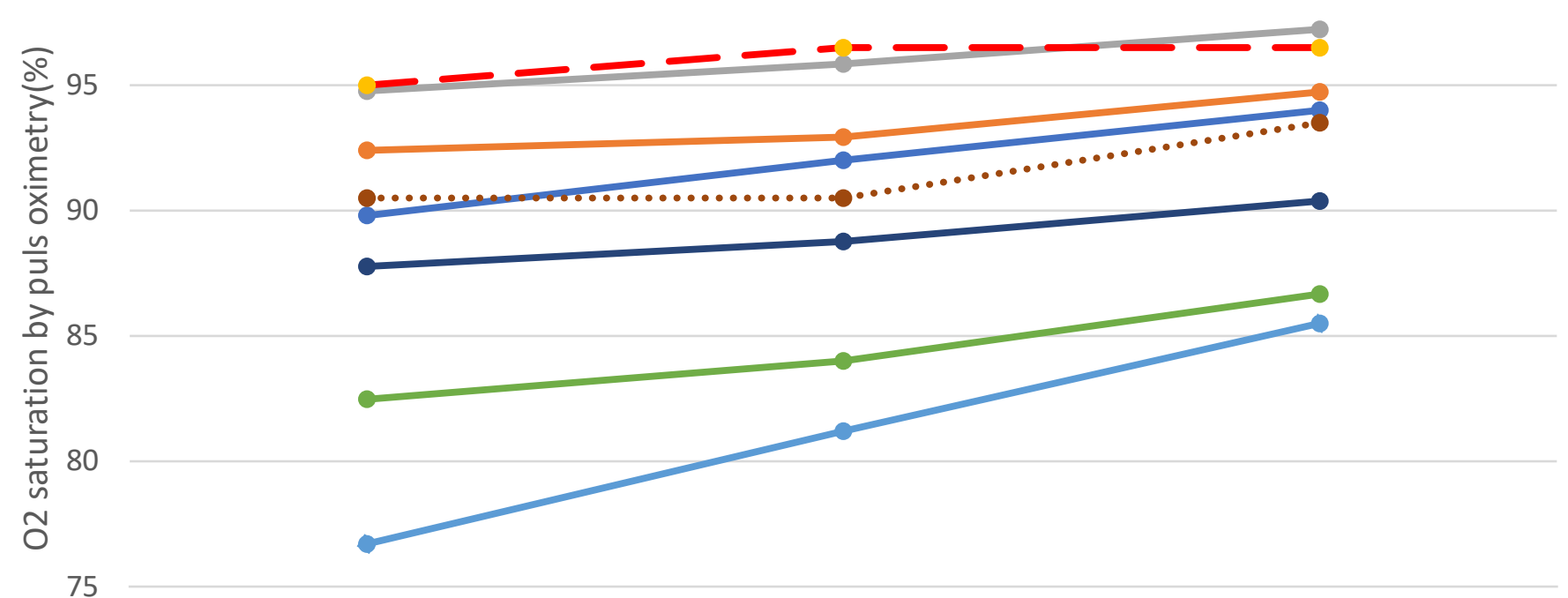

Day 1

Day 2

Day 3

O2sat with $\mathrm{O} 2$ therapy-SG1 of intervention

- O2sat with 02 therapy-SG2 of intervention

- O2sat with $\mathrm{O} 2$ therapy-SG3 of intervention

- O2sat with $\mathrm{O} 2$ therapy-SG4 of intervention

$\leadsto$ O2sat without 02 therapy-SG1 of intervention O2sat without 02 therapy-SG2 of intervention

$\longrightarrow$ O2sat without $\mathrm{O} 2$ therapy-SG3 of intervention O2sat without $\mathrm{O} 2$ therapy-SG4 of intervention 
medRxiv preprint doi: https://doi.org/10.1101/2021.07.27.21260398; this version posted July 27,2021 . The copyright holder for this preprint (which was not certified by peer review) is the author/funder, who has granted medRxiv a license to display the preprint in perpetuity. It is made available under a CC-BY-NC-ND 4.0 International license .

Table1. Comparison of Demographic characteristics between intervention and control groups

variable

Gender, N (\%)
Control

M 25(62.6)

F $15(37.5)$
Intervention

M 24 (60)

F $16(40)$
P-value

0.83

$58 \pm 17.13$

0.82

$26.81 \pm 3.14$

0.96

\section{Lung lesions-CT}

Multilobar, n (\%)

Unilobar, n (\%) 
medRxiv preprint doi: https://doi.org/10.1101/2021.07.27.21260398; this version posted July 27,2021 . The copyright holder for this preprint

(which was not certified by peer review) is the author/funder, who has granted medRxiv a license to display the preprint in perpetuity.

It is made available under a CC-BY-NC-ND 4.0 International license .

Table2. Comparison of Modified 0-10 Borg Dyspnea Scale and peripheral oxygen saturation $\left(\mathrm{SpO}_{2}\right)$ between the two groups $(\mathrm{M} \pm \mathrm{SD})$

SpO2-without 02 therapy $(\%)$

$1 \quad 84.65 \pm 3.58$

$83.15 \pm 4.84$

0.12

SpO2-without O2 therapy (\%)

2

$85.90 \pm 3.11$

$85.18 \pm 4.66$

0.76

3

$87.88 \pm 3.17$

$5.61 \pm 2.16$

$5.76 \pm 2.36$

0.77

Modified Borg Scale-at rest

Modified Borg Scale -after 50m walking
$4.56 \pm 2.28$

0.19
0.007

0.91
0.95

.77

$3.90 \pm 2.17$

$2.72 \pm 2.25$

$7.20 \pm 2.01$

$6.45 \pm 1.91$

$6.57 \pm 1.91$

0.77
2

3
$4.53 \pm 2.04$

$3.52 \pm 1.66$ 
medRxiv preprint doi: https://doi.org/10.1101/2021.07.27.21260398; this version posted July 27, 2021. The copyright holder for this preprint (which was not certified by peer review) is the author/funder, who has granted medRxiv a license to display the preprint in perpetuity.

It is made available under a CC-BY-NC-ND 4.0 International license .

Table3. Comparison of peripheral oxygen saturation $(\mathrm{SpO} 2)$ between subgroups $(\mathrm{M} \pm \mathrm{SD})$

Sp02 with 02-therapy

Number
Sp02 without 02-therapy

pre post

pre

$$
\begin{array}{llllll}
\text { intervention }(n=10) & \begin{array}{l}
M=5 \\
F=5
\end{array} & 89.8 \pm 2.74 & 94 \pm 6.31 & 76.7 \pm 2.75 & 85.5 \pm 3.54
\end{array}
$$

SG.1

\begin{tabular}{ccccccr} 
control(n=3) & $\mathrm{M}=2$ & \multicolumn{3}{c}{$0.89^{*}$} & & \\
& $\mathrm{~F}=1$ & $88.33 \pm 1.53$ & $93 \pm 2$ & $79 \pm 0.0$ & $85 \pm 3.46$ \\
\hline \multirow{2}{*}{ intervention(n=15) } & $\mathrm{M}=9$ & & & & \\
& $\mathrm{~F}=6$ & $92.4 \pm 2.99$ & $94.73 \pm 5.81$ & $82.47 \pm 1.3$ & $86.67 \pm 4.3$
\end{tabular}

SG.2

\begin{tabular}{|c|c|c|c|c|c|c|c|}
\hline $\operatorname{control}(n=18)$ & $\begin{array}{l}M=9 \\
F=9\end{array}$ & $92.7 \pm 1.97$ & $94.5 \pm 2.71$ & & $82.11 \pm 1.45$ & $86.33 \pm 2.91$ & $.98^{\circ}$ \\
\hline intervention $(n=13)$ & $\begin{array}{l}M=6 \\
F=7\end{array}$ & $94.77 \pm 2.42$ & $97.23 \pm 1.92$ & \multirow{2}{*}{$0.88 *$} & $87.77 \pm 1.67$ & $90.38 \pm 3.1$ & \multirow{2}{*}{$0.58 *$} \\
\hline $\operatorname{control}(n=15)$ & $\begin{array}{r}\mathrm{M}=7 \\
\mathrm{~F}=8\end{array}$ & $93.53 \pm 1.36$ & $96.13 \pm 2.5$ & & $87.4 \pm 1.29$ & $89.47 \pm 2.1$ & \\
\hline intervention $(\mathrm{n}=2)$ & $\begin{array}{l}M=0 \\
F=2\end{array}$ & $95 \pm 1.14$ & $96.5 \pm 2.12$ & \multirow{2}{*}{$0.86^{*}$} & $90.5 \pm 0.7$ & $93.5 \pm 2.12$ & \multirow{2}{*}{$0.42 *$} \\
\hline $\operatorname{control}(n=4)$ & $\begin{array}{l}\mathrm{M}=2 \\
\mathrm{~F}=2\end{array}$ & $94.5 \pm 1.29$ & $96.5 \pm 2.4$ & & $90 \pm 0.0$ & $91 \pm 2.45$ & \\
\hline
\end{tabular}

*Comparison of $\mathrm{O} 2$-sat level changes after three days of intervention with the same subgroup.

$\mathrm{M}=$ male, $\mathrm{F}=$ female 